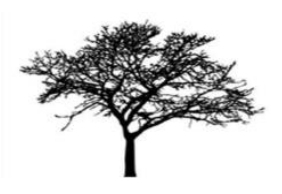

AVRASYA Uluslararası Araştırmalar Dergisi

Cilt : 8 Sayı : 25 Sayfa: 272 - 284 Aralık 2020 Türkiye

Araştırma Makalesi

\title{
THE TRANSFORMATION OF PUBLIC AND PRIVATE SPACES ALONG ISMET INONU-2 BOULEVARD
}

Arş. Gör. Dr. Fatma KOLSAL *

Dr. Öğr. Üye. Hatice Günseli DEMiRKOL**

\begin{abstract}
The aim of this study is to examine the changes in the identity of the Ismet Inönü-2 Boulevard in the Eskişehir Old Factory Area through the transformation of public and private spaces in historical context. In the study, first, the three eras that are; the development of the Boulevard due to the industrialization of the Early Republican period, the situation up to the year 2000 and the rapid transformation process witnessed after 2000 will be given chronologically. Then, spatial transformations on the Boulevard, which are the indicatives of the socio-economic changes, will be discussed through concepts derived from the literature survey. These concepts will also be exemplified and concretized through the field work conducted in the Boulevard. It is inferred from the investigation that the identity of the Boulevard related to industrialization and production disappeared and a new identity has arisen due the consumption spaces such as Cafés, Restaurants, Hotels, Office Blocks and Shopping Centers surrounding the Boulevard through the revisions of the development plans. According to the findings obtained during the study, İsmet Inönü-2 Boulevard reflects socio-economic transformations with the qualities and the transformations of the private and public spaces it hosts. The street, which is re-structured evolving from the production society to the consumer society, is an "invented street" and the interface built on the street produces private publicities and excludes the public.
\end{abstract}

Keywords: Public Space, Private Space, İsmet Inonu-2 Boulevard, Eskişehir, Consumption

\section{ISMET INÖNÜ-2 BULVARI'NDAKI KAMUSAL VE ÖZEL ALANLARIN DÖNÜŞÜMÜ}

\section{ÖZ}

Bu çalışmanın amacı, Eskişehir Fabrikalar Bölgesi'ndeki İsmet İnönü-2 Bulvarı'nın kimliğindeki değişimleri tarihsel süreç- içerisinde kamusal ve özel mekânların dönüşümü üzerinden irdelemektir. Çalışmada önce, Bulvarın Erken Cumhuriyet Dönemi sanayileşmesine bağlı gelişimi, 2000 yılına kadar olan durumu ve 2000 sonrası tanık olduğu hızlı dönüşüm süreci kronolojik olarak aktarılacaktır. Ardından, sosyo-ekonomik değişimlerin göstergesi olan bulvardaki mekânsal dönüşümler yazın araştırması ile elde edilen kavramlar aracılığıyla tartışılacaktır. Bu kavramlar, bulvarda yapılan alan çalışması ve fotoğraflamalar ile somutlaştırılacak ve örneklendirilecektir. . Çalışmada bulvarın sanayiye ve üretime dayalı kimliğinin yok olduğu ve imar planındaki revizyonlarla bulvarın Kafe, Restoran, Otel, ofis blokları ve Alış-veriş merkezleri gibi tüketim mekânları ile çevrelenerek yeni bir kimliğe büründüğü görülmüştür. Bulvar üzerindeki kamusal ve açık alanların niteliğinin bu yeni kimliğe göre şekil aldığı tespit edilmiştir. Çalışmadan elde edilen bulgulara göre, İsmet İnönü-2 Bulvarı, barındırdığı kamusal ve özel mekanların nitelikleri ve geçirdiği dönüşümler sosyo-ekonomik dönüşümleri yansıtmaktadır. Üretim toplumundan tüketim toplumuna evrilen yapı içerisinde yeniden yapılanan cadde, "kurgulanmış" bir sokak olup, caddede inşa edilen arayüz, özelleşmiş kamusalıklar üretmekte, kamusalı dışlamaktadır.

* Eskişehir Teknik Üniversitesi, Mimarlik Ve Tasarim Fakültesi, Mimarlik Bölümü, Bina Bilgisi Anabilim Dali, fatma.kolsal@gmail.com, Orcıd ID: 0000-0002-5569-2046

* Eskişehir Teknik Üniversitesi, Mimarlik Ve Tasarim Fakültesi, Mimarlik Bölümü, Yapi Bilgisi Anabilim Dali, hgdemirkol@gmail.com, Orcıd ID: 0000-0002-2301-3766 
Anahtar Kelimeler: Kamusal Alan, Özel Alan, İsmet İnönü-2 Bulvarı, Eskişehir, Tüketim

\section{INTRODUCTION}

Eskişehir is one of the most noteworthy industrial cities of Early Republican Period in Turkey. By the introduction of industrial areas to the city, the morphology of Eskişehir has considerably been changed. Factory District and Ismet Inonu-2 Boulevard are formations with a central role regarding the new urban patterns. Most recently, in common parlance, the street is referred as "Boulevard of Prestige", which reveals multiple arguments about the socio-economic and socio-cultural reflections signifying a transformation in the use of public and private spaces. In this study a metaphoric re-structuring of the society is scrutinized through the physical restructuring of the street, namely Ismet Inonu-2 Boulevard, utilized as an architectural timeline. The interventions and transformations in the spaces of production are deciphered through an architectural reading.

As Kostof (1985: 19) states, “...architecture is a medium of cultural expression only to the extent that we are able to absorb its messages. And these messages are elicited through the questions that are preoccupying us today. The way we interpret the culture of a period or a nation through its architecture may tell us as much about it as about ourselves".

This text is to understand and to interpret the restructuring of a street - İsmet İnönü-2 Boulevard- regarding the public and private spaces. To do so, Ismet Inonu-2 Boulevard is utilized as an architectural timeline and the transformation of the society is scrutinized through the physical restructuring of the street. The changes in the identity of the Ismet Inönü-2 Boulevard is examined through the transformation of public and private spaces in historical context.

The physical context of the study includes the section between Kanatlı Shopping Mall and Özdilek Shopping Mall, whereas the context for time focus on the period after the year 2000 (Figure 1 and 2). The year 2000 is important because the stable appearance of the street for decades has started to change from 2000 on. The rapid restructuring and interventions have remarkably taken place along the street after the year 2000 .

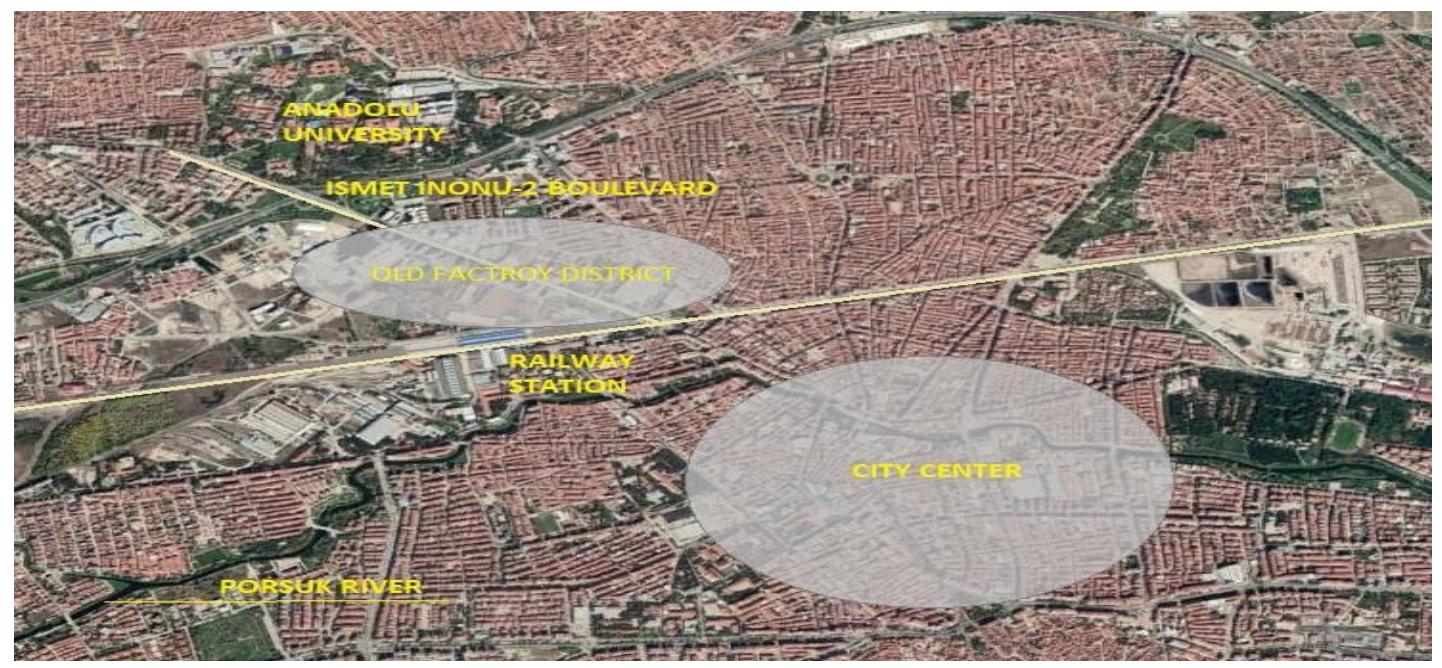


Figure 1. Aerial photograph of Eskisehir displaying the location of the "Old Factory District" in relation with the city center and the railway route (source: GoogleEarth, last visited on 21.10.2020)

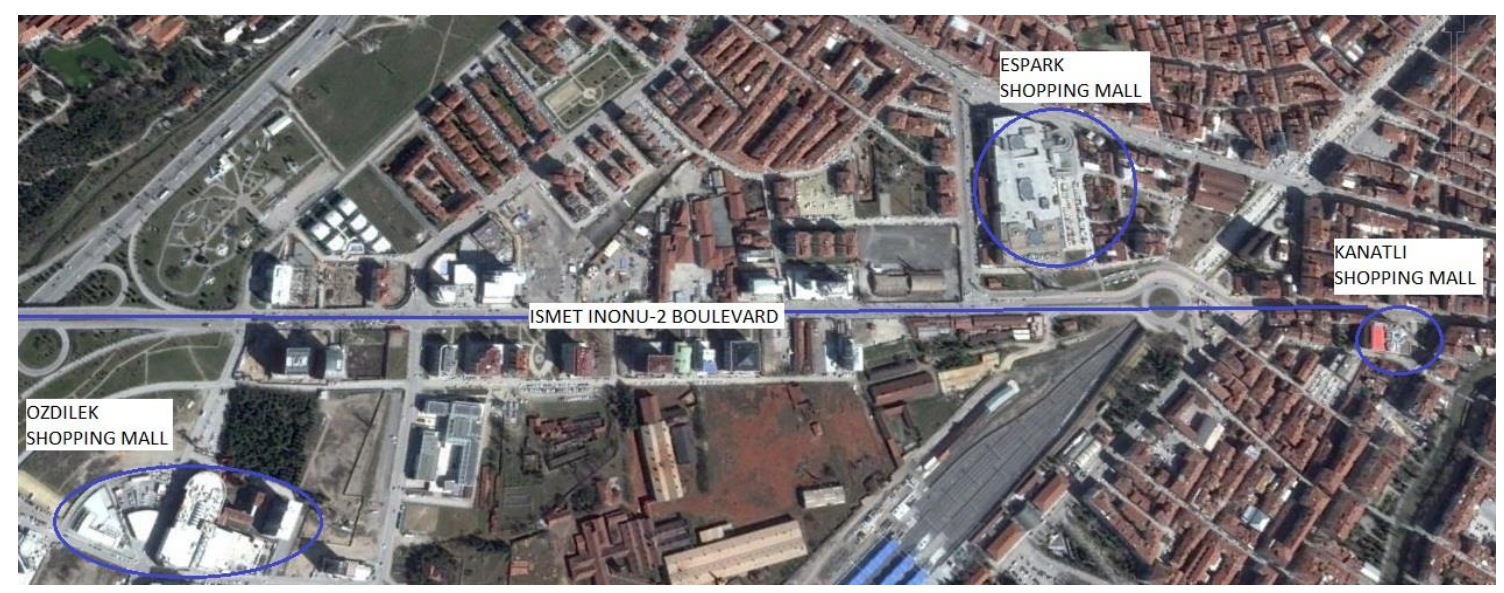

Figure 2. 2015 Aerial photograph of the İsmet İnönü-2 Boulevard (source: GoogleEarth, last visited on 30.12.2015)

\section{THE METHOD OF THE STUDY}

In the study, the development of the Boulevard due to the industrialization of the Early Republican period, the situation up to the year 2000 and the rapid transformation processes that were witnessed after 2000 are explained and interrogated chronologically. Spatial transformations on the Boulevard, which are indicative of socioeconomic changes, is discussed through concepts derived from the literature survey. Literature survey includes architectural subject matters, as well as urban and social issues. In addition, the concepts in discussion are exemplified and concretized through the field work in the Boulevard.

\section{THE SITUATION OF THE BOULEVARD BEFORE 2000}

Eskişehir has always had an important position in Turkish urban history. This position had been emphasized during the Early Republican Period, due to the fact that it is one of the most industrialized Anatolian cities in Turkey. Industrialization had central importance to the new-born Republic in the conspicuous absence of an autonomous bourgeoisie class in order to create financial opportunities. The industrial settlements were, indeed, the most significant architectural extensions of the Kemalist project of modernity into Anatolia (Bozdoğan 2008: 433-434). Thus, not only the factories but also a modern way of life was constructed during this period.

In Republican Period, besides state-sponsored industrial developments, there were investments on soil, brick, and tile as well as food industry done by private sector in Eskişehir. The major part of private factories was constructed and spread over an area of 62 hectares in the north of the railway, which is called "Factory District". This district had a great impact on the formation of the macro form of the city (Aksoylu 2012: 48) (Figure 3). 


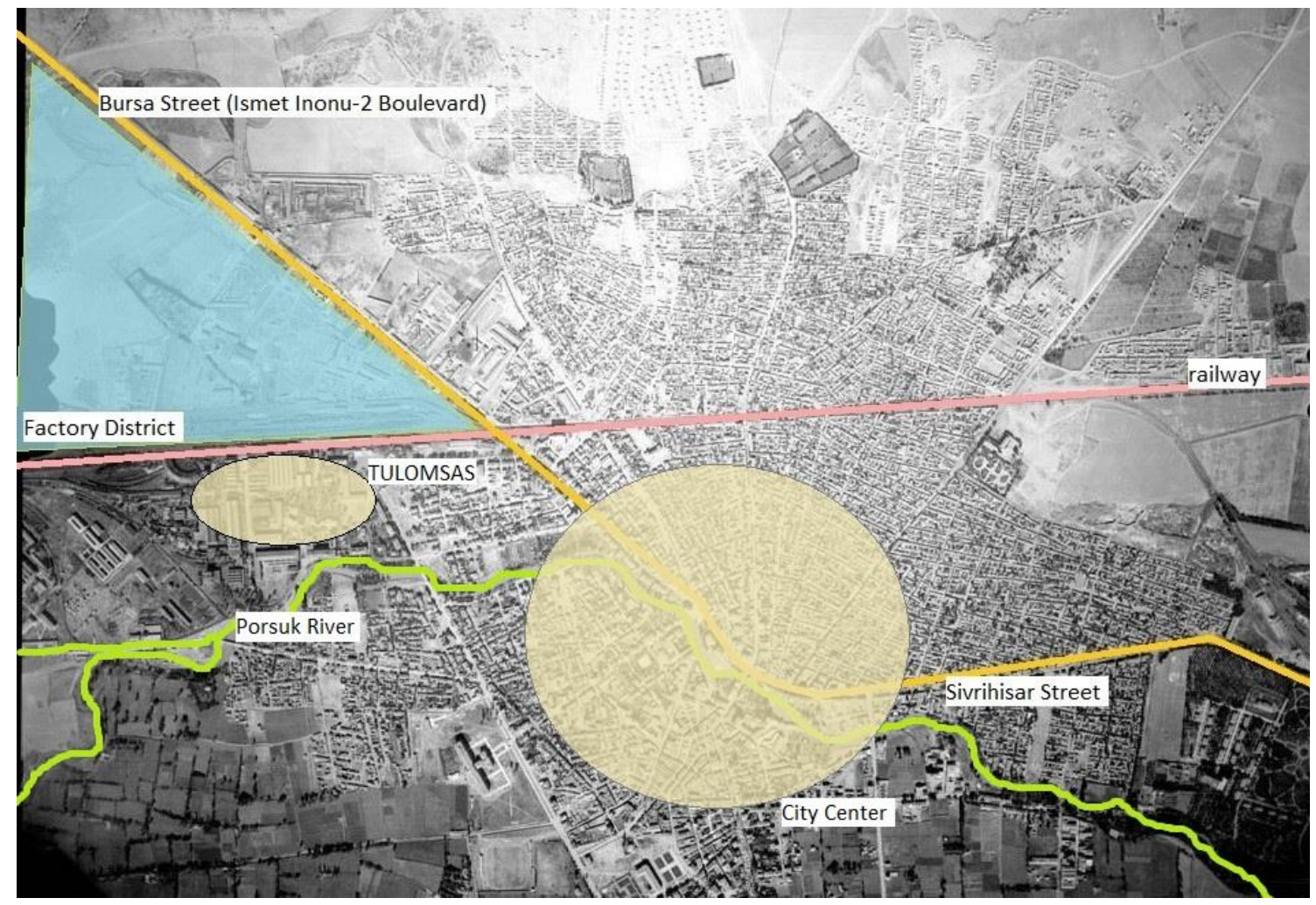

Figure 3. Eskişehir in 1950 displaying the relation in between Factory District and İsmet İnönü-2 Boulevard (produced after the aerial photograph is obtained from General Command of Mapping)

The close relation in between the work place and home had caused the residential dwellings to occur in the vicinities of the factories which had also given direction to the formation of the street network, as much as to the shifting of the city center and to the location selection of the recreational areas. (Aksoylu 2012: 55)

Ismet Inonu-2 Boulevard, once called as "Bursa Street", is a formation with a central role regarding those urban configurations. The Bursa Street, which dates back to Ottoman Period, had been rehabilitated and enlarged for a better service during Republican Period. It was the main motorway which connects Eskişehir to İstanbul and Ankara until the 1960s. After the 1960s the street had become more effective on the urban dwelling patterns rendering its service functions secondary. This situation was supported by the alternative motorways providing connection to Istanbul and Ankara. Considering its relation to the Factory District, the new residential districts participated to the urban morphology of the city along this street (Ertin 1994:134).

Parallel to the rapid urbanization of Eskişehir in the 1950s, the production in the factories had stopped in the course of time especially after 1980s. The industrial settlements had been surrounded by an urban fabric making the position of them quite valuable for their vast lands remained in the city center. Consequently, the factories were abandoned and found a new location outside the city (Aksoylu 2012: 55). Having a very important effect on creating the city image with their vertical chimneys and brick colored configurations, this district, therefore, have become very attractive for the urban 
transformation, especially for the private investors/constructors, owing to the fact that it is very close to the center and main axles of the urban transportation. Moreover, especially after 1995 , the decision taken by the municipality about the division of the industrial lots to smaller ones was the trigger of such a transformation. In 2003, some of the industrial settlements were registered as industrial heritage and most of them determined as socio-cultural activity areas besides having commercial identities. The transformation implies a variety of events such as destruction of old industrial settlements, re-functioning of old industrial settlements, and constructing new buildings. As a result of these developments the story about the re-structuring of the street towards the "Boulevard of Prestige" has started.

Regarding its history, it can be said that İsmet İnönü-2 Boulevard had not always had a public and convivial character. It was a fundamental network element of the city before Republican period- that is to say before modernization- however, this role was merely a functional one rather than a public one. The publicness of it was visible only after the street had a communication with the dwellings around and stroke to a more dominating attitude creating a linkage between the domestic spaces and the work spaces. Moreover, this character was fortified by the introduction of Anadolu University along with the east side of the street in 1958. So, a social and urban ground is necessary to base the evaluation of the public and private spaces, since it is impossible to talk about the publicness where there is no life around. Therefore, the 1950s can be accepted as the initiation of such a publicness for İsmet İnönü-2 Boulevard, since the street had started to be involved in the lives of people.

For a street, Goldberger (1996: 170) says "...it is the building block of urban design and, by extension, of urban life; the city with vibrant street life is the city that works as a viable urban environment and where the real life goes on". Thus, the very spirit of the street is already public. In the 1950s, when Factory District was very active, İsmet Inönü-2 Boulevard is told that it is used by working men to arrive at the factories they are employed in. Most of them had used bicycles and ride through the street. Those times supposed to be the period in which the consequences of modernization had started to be felt. As Sennett (1999: 14) states, one of these consequences is the core of modern culture about the separation between the concept of "in" and "out". This is a separation of the subjective life from the worldly and of ego from the city. This statement had been proved by the separation and specialization of all parts of our lives. It started in the public life and continued in the private life. The separation, similarly to the one occurred in the street, led to an isolation in the house as well (Sennett 1999: 45). In other words, the modernization brought about a rational and functional division both in the urban and domestic scale.

According to these statements, it can be said that İsmet İnönü-2 Boulevard and the edifices alongside was a part of such kind of a rational and functional planning approach. In the 1950s, the factories especially established by private initiations had found a location in the northern portion of the city. This was on purpose and had the rationality of creating an industrial zone which had a close position both to railway and motorway. It is not surprising that each building of those industrial settlements reflects the same approach, too. In other words, they were all built in the rationality of 
production. As a result of this, the street was totally flanked by industrial buildings and stayed so until the 2000 s.

\section{THE SITUATION OF THE BOULEVARD AFTER 2000}

The transformative actions have started after the municipal decisions assigned a new function for the area. It is the turning point of the region in terms of getting out of an identity related to production and gaining a recent one related to consumption. There is no doubt that urban decisions have great effect on the formation of a city (Benliay et al., 2015: 40). The most striking development and the signal for a change were the introduction of the tram to the urban circulation of Eskişehir in 2004 (www.eskisehir.bel.tr), which at the same time passed through İsmet İnönü-2 Boulevard. By this way, the accessibility of the street has increased. However, the following two occurrences had an incomparable effect on the progress of the street: the opening of two shopping malls in 2007; Kanatlı and Espark Shopping Malls successively (Üstün and Tutal 2008: 272).

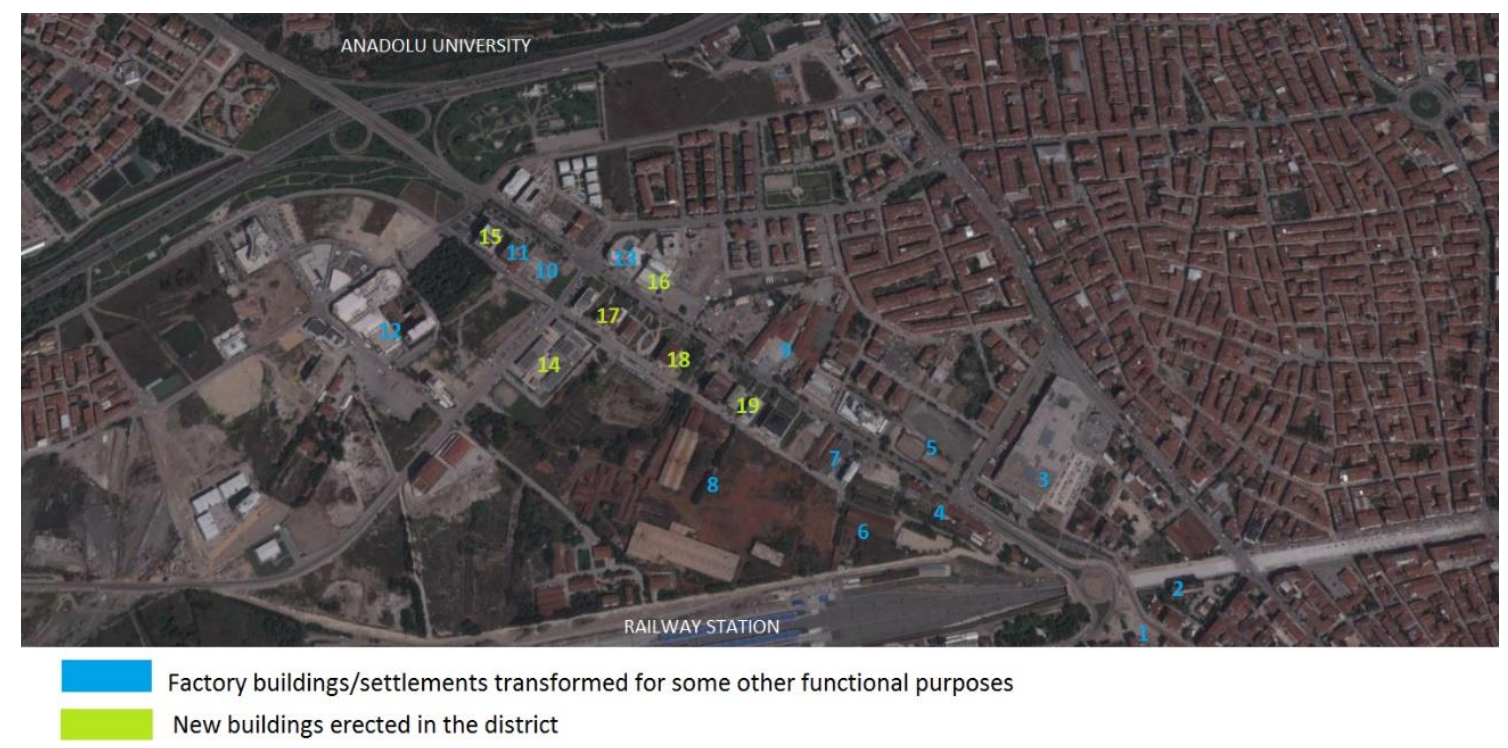

Figure 4. The aerial map showing the existing, transformed and introduced buildings regarding the area (source: Google Earth, last visited on 30.12.2015)

Not surprisingly, those two commercial buildings were constructed in the place of abandoned factories. Kanatlı Shopping Mall was erected after the demolition of Kanatlı Flour Factory, whereas Espark Shopping Mall was built after the destruction of a brick and tile factory. Another contribution to the new commercial character of the street was done by 222 Park nightclub, which was housed in a lumber factory after a restoration project in 2008. This was a quite crucial development opening new perspectives for the transformation of the region. Finally, the introduction of the building of Tepebaşı Municipality along the street in 2009, escalated the re-structuring (Figure 4).

After these initial interventions, the change in the street has accelerated. Now, the actual condition of the street bears numerous types of buildings, except for the factories. These types can be counted as retail buildings, high-rise office blocks, mixed 
used office and residential blocks, nightclubs, pubs, restaurants, cafes, bars, hotels, and shops (Table 1).

Table 1. The list of buildings in the district and their history of demolition or transformation

\begin{tabular}{|c|c|c|}
\hline Buildings & Transformation/Intervention & Date \\
\hline \multicolumn{2}{|l|}{ Introduction of Tram } & 2004 \\
\hline 1- Kanatli Flour Factory & 1- Kanatli Shopping Mall & 2007 \\
\hline 2- The Soil Products Office Silo & 2- Ibis Hotel & 2007 \\
\hline 3- Baskurt Brick\&Tile Fact. & 3- Espark Shopping Mall & 2007 \\
\hline 4- Dogrular Lumber Factory & 4- 222 Park Night club & 2008 \\
\hline \multicolumn{3}{|l|}{ 5- ÇiftKurt Brick\&Tile Fact. } \\
\hline \multicolumn{3}{|l|}{ 6- The Soil Products Office Warehouse } \\
\hline 7- Aral Wine Factory & 7- Hayal Kahvesi (Retail) & 2007 \\
\hline \multicolumn{3}{|l|}{ 8- Kılıçoğlu Tile Factory } \\
\hline \multicolumn{3}{|l|}{ 9- ETI Biscuits Factory } \\
\hline \multicolumn{3}{|l|}{ 10- Yasin Çakır Flour Fact. } \\
\hline 11- Öc Tire rim Fact. & 11- Buda Bar (Retail) & 2007 \\
\hline 12- Mühendisler Flour Fact. & 12- Özdilek Shopping Centre & 2012 \\
\hline 13- Fil Tile Factory & 13- Dedepark Hotel & 2010 \\
\hline 14- Tepebaşı Municipality & & 2009 \\
\hline $15-16-17-18-19$ & $\begin{array}{l}\text { Multi-functional office blocks (Iki Kule, } \\
\text { Modernity, Basak Residence) }\end{array}$ & $2010-\ldots$ \\
\hline \multicolumn{2}{|c|}{ Demolition of the Bridge passing over the railway } & 2013 \\
\hline
\end{tabular}

According to Ray Oldenburg (1989: 165), such spaces can be called as "third places". On contrary to the first place of home or the second place of work or school, the third places are a kind of in limbo spaces. Necessarily, a transformation should occur when passing through the portals of a third place. Externally, those who receive respect and attention according to the weight of their position find themselves in the third place in places where traditional status is very low.

There was a motorway bridge passing over the railway line, which could be accepted as the initial point of the İsmet İnönü-2 Boulevard in the south. This bridge was a physical obstacle slowing down the pedestrian flow towards the Anadolu University. In 2013, after the demolition of the bridge letting tram to pass the railway line, the physical connection of the Boulevard to the city center has strengthened and accessibility to the street has relatively eased. Collectively, these events lead to a total transformation as much in the physical characteristics of the street as the public and private spaces it holds.

According to Banerjee (2001: 11), public space is linked with recreative spaces such as parks, playgrounds, or systems of open space that are obviously in the public 
realm. This is one side of the critiques towards the contemporary public space. For Carmona (2010), most of these evaluations for the exclusionary and increasingly privatized public realm is done because of commodification and homogenization of the space. Most of the time, this assessment is due to a managing and designerly point of view. Besides, the loss of authenticity and the increasing feel of "placelessness" supports the idea of "invented" space. For many urban researchers, the sense that the public realm is weakening by a growing trend of what is commonly described as "privatized" public spaces or "publicized" private spaces. There is an ideal of "publicness" in the designated public spaces, but in fact, they belong to the private realm. The public is favoured as long as they are able to afford the privatized public services. Under these conditions, the access to and use of the space is only a privilege, it is not a right (Banerjee 2001: 12). These expressions resemble the current condition of İsmet İnönü-2 Boulevard since there are similar spaces as Banerjee describes in his text. Moreover, he calls such kind of streets as "invented streets" due to the designed and organized aspects of them for the purpose of consuming. In the case of İsmet İnönü-2 Boulevard, however, it can be said that it is a natural street with an unnatural development. When the life story of this street is observed, similarities with Haussmannization of the $19^{\text {th }}$ century can be read.

As Harvey, Benjamin and Sennett raised in their works, Haussmannization is a very strong concept to read the impact of architecture on a new way of life. Baudelaire is a key figure to understand the social and societal divergences at that time as well. His concept of "Flânerie", is connected to the desire for relaxation, social contact, entertainment, leisure, and the actions related to having a good time (Benjamin 1995: 130; Sennett 1999:175).

Exemplifying the public and private spaces through a poem of Baudelaire, in which two lovers split up due to their different approaches to a man outside of the café of which they were in, Harvey (2006: 18-19) underlines a sense of space where ambiguities of proprietorship, of aesthetics, of social relations and the political economy of everyday life, collide. Furthermore, the new boulevards were constructed as public spaces to facilitate the state's protection of bourgeois private property. Banerjee (2001: 14) supports the same idea emphasizing the blurriness of the line between public and private spaces as in the case of Parisian arcades.

Another correlation is the intentions of Haussmann himself. Haussmann sought to expel industrial activities and its associated working classes from the center of the city. He strictly mandated design criteria and aesthetic forms for both public and private construction on and around the boulevards (Harvey 2006: 21).

Thus, regarding its formation and content with the character of public and private spaces, İsmet İnönü-2 Boulevard could be a creation of a political desire which belongs to a more global attitude. As in the case of Parisian boulevards, it bears public spaces. Nevertheless, their role as private places at the end diminishes their public character, whatever the architectural achievement they represent. They are not made over time like real living streets; they are produced by designers not to create culture but to consume it (Goldberger 1996: 174). 
Consequently, the industrial character of the street emptied by the consumerist approaches in city development decisions. The physical aspects of the existing urban landscape, which are in parallel with those consumerist developments stayed as they are - such as the façade of the factories with new retail functions, or chimneys symbolically preserved to refer to the past industrial city image. By this means the unprofitable old city values are swept away. 222 Park night club, which was housed in a lumber factory after a restoration project in 2008, is a good example for the symbolic preservation, while Özdilek Shopping Mall, newly planned and built on the parcel of the demolished Mühendisler Flour factory from the 1920s exemplifies the sweeping away of the "old" for the sake of the "new" (Figure 5).

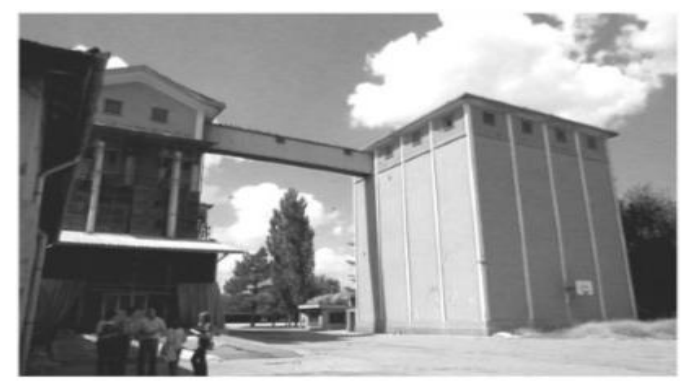

Figure 5. Mühendisler Flour Factory totally demolished in order to erect Özdilek Shopping Mall

Lefebvre (1973: 143) properly describes this situation in his discussion of the production of the space: ".... are liable to discover how such spaces may be pressed into the service of cultural consumption, of 'culture itself', and of the tourism and the leisure industries with their almost limitless prospects... When destruction has not been complete, 'renovation' becomes the order of the day, or imitation, or replication, or neothis or neo-that. In any case, what had been annihilated in the early frenzy of growth now becomes an object of adoration."

Seemingly, the re-structuring of the new boulevard implies to the re-functioning of its physical elements both in a destructive and in a transformative way (Figure 6). It reveals that three major trends- privatization, globalization, and the communications revolutions- continue to form, direct and produce the future demand and supply of public space. Public life both encompasses private and public realms. Collectively, these approaches represent main transformations in the way public life and space are perceived, conceptualized and in the values associated with them. Future designs and plans for public space must be based on an understanding of the causes and consequences of these trends and the changing nature of public life (Banerjee 2001: 910). 

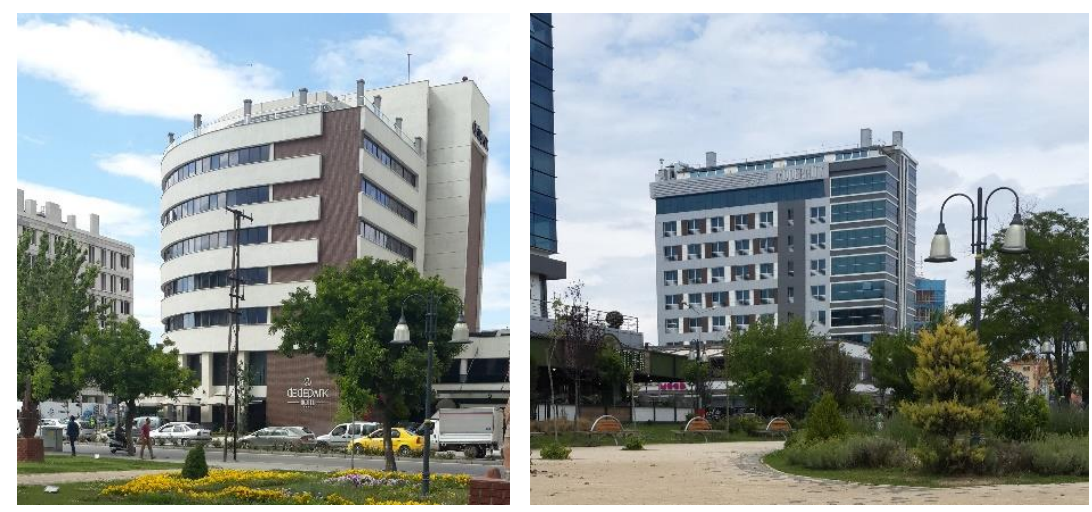

Figure 6. Left: Dedepark Hotel which is erected in the place of Fil Tile Factory; Right: Modernity Hotel a newly introduced building along the street with a retail function on the ground floor (Kolsal, June 2016)

In line with Banerjee, it is observed that İsmet İnönü-2 Boulevard has open spaces both publicized private identity and privatized public identity. In his paper, defining the "openness of the open space", Lynch (1990:21) sets the criteria for a good and public open space. Starting from the very meanings of the word "open", he starts a semantic and linguistic discussion in order to better describe the space. Openness can be the accessibility as well as not being closed. Whatever it is, according to Lynch, open space he is describing should be public and determined by some building blocks.

With respect to these definitions, the open spaces in between office blocks having access from the street and the retail spaces on the ground floor of the blocks can be counted as open public spaces. However, their connection and vicinity to the private third places render those open spaces privatized and create an invisible boundary. Especially, the open space in front of "Iki Kule" (Two Towers), is a good example for this since it has a complementary design with the building blocks behind. It gives the impression that it belongs to the proprietorship, not to the public, even if it is an open space (Figure 7).
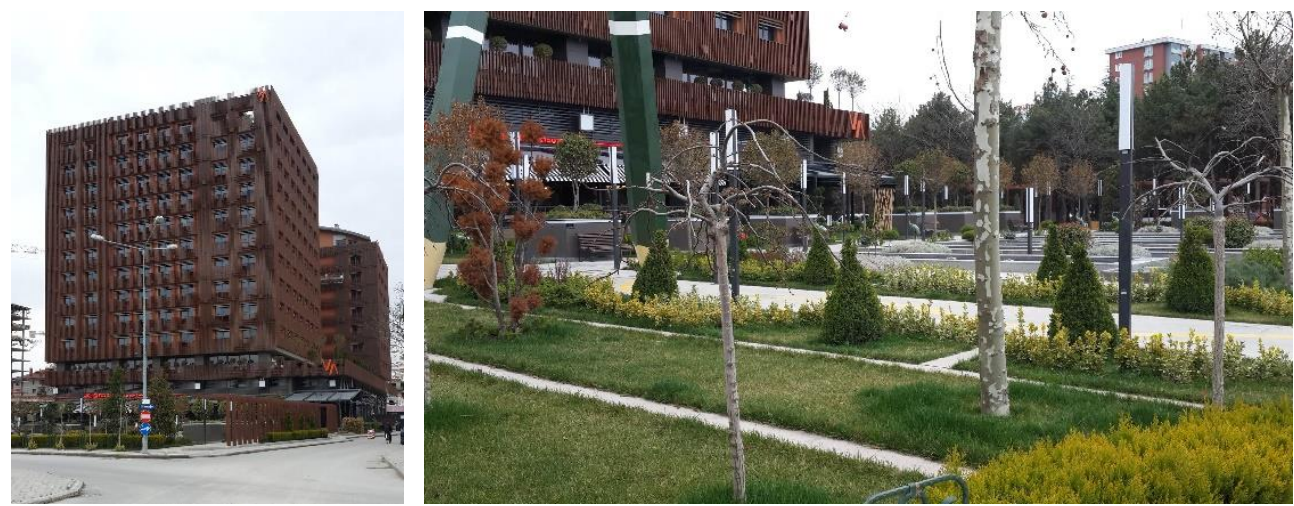

Figure 7. One of the office blocks (Iki Kule and Hilton Hotels) on the street and the open space in front of it, the ground floor has a retail function as a pub and cafe (Kolsal, 2016)

Another exemplifying privatized open space is the voids in between newly erected multifunctional office blocks those of which have a relation to the ground floor by some retail purposes. The landscape design and the organization of them include 
some public messages, yet they are far from being defined and publicized since they serve as the backyard or front yard of the third place they are adjacent to (Figure 8).
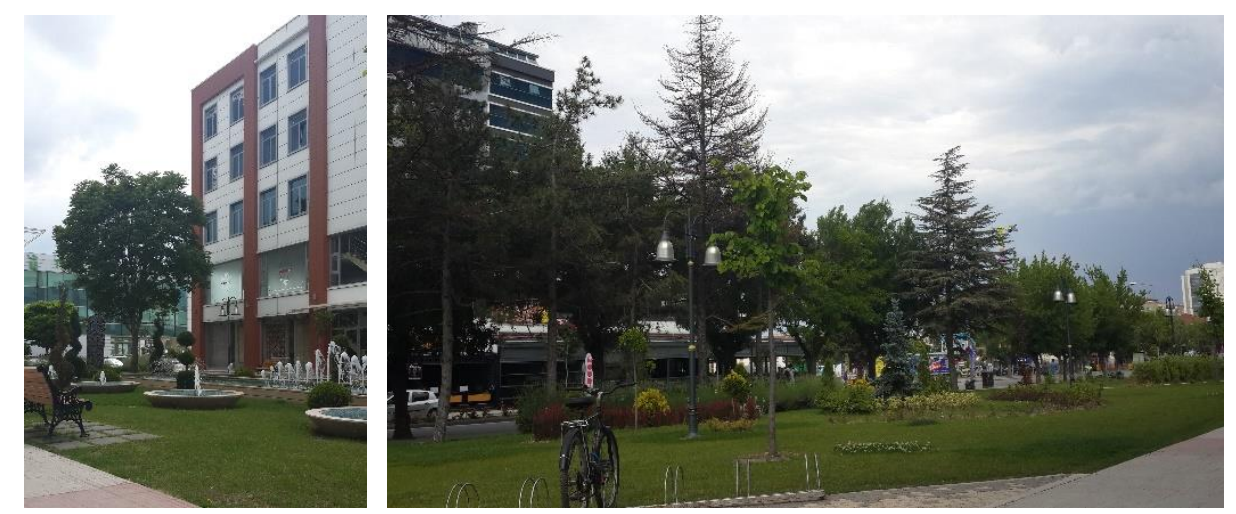

Figure 8. Commercial buildings and the hotel called "Modernity" (Kolsal, 2016)

The last but not the least issue is shopping malls and their publicness. After the introduction of Kanatlı and Espark Shopping Malls, there was another consumption place constructed in 2012, called Özdilek Shopping Mall. This commercial center is also the terminal point of the axle interrogated. The proliferation of such productions of the consumer culture feeds back the consumption and produces the very culture itself. In addition to that, shopping malls are the new downtowns and they create an illusion of public space.

Although shopping centers look like public spaces, they are not entirely public, and shopping activity is expected first (Özdemir et al., 2016: 60). For the sake of safety, purity, hygiene, and homogeneity, the unholy and unwashed are excluded from the privatized public spaces. It is a kind of constructing an analogous city.

\section{CONCLUSION}

In conclusion, İsmet İnönü-2 Boulevard is invented by the political and economic underlying causes with the direction of privatization, globalization, and the communications revolutions. The architectural expression of the street is the reflections of such an effect creating spaces according to the needs of the era. Yet, most of the time it is a superficial creation addressing to the facades rather than spaces. The façade communicates with people in various ways telling stories about the fashion, the status and, the significations.

Lynch was interested in the clear definition of the open space by the building blocks. According to him it was a matter of the correct organization of the void and the solid. Although there are spaces opened and defined enough to fit the descriptions of Lynch, it seems they are far from socio-cultural correctness since they lack publicness. The reason for this is the language of the facades implying to a privatized publicness. The more space - the façade, the street, the building- is designed, the more every day and public life are excluded.

Here, on İsmet İnönü Boulevard-2, an illusion is presented regarding the public space. There are physically public spaces, but they are not public in the soul. Even though most of the new buildings have inviting open spaces with their lovely landscape design, they behave like the trailer of something chargeable. They are colorful, 
convivial and calling (Figure 4), with the message "as long as you pay for it". Hence, the invisible boundaries created by the communicative ends of the design starts to work. In such a system, it is hard to believe in the publicness of the street as well, which is flanked by similarly designed buildings. Those spaces are an outcome of a consumerist society; they at the same time become the factories of such a culture. As the society is consuming, no matter the public realm continues in a public or a private space, because the societal reality does not concern the difference.

\section{REFERENCES}

AKSOYLU, Sevin, (2012), "Cumhuriyet Dönemi'nde Sanayi Tesislerinin Eskişehir'in Mekansal Gelişimine Etkileri”, Eskişehir Valiliği, Eskiyeni Dergisi, Year:4, p. 48-56

BANERJEE, Tridib, (2001), The Future of Public Space: Beyond Invented Streets and Reinvented Places, Journal of the American Planning Association, Winter 2001, Vol:67, No:1, Routledge

BENJAMIN, Walter, (1995), Pasajlar, İstanbul: Yapı Kredi

BENLIAY, A., SOYDAN, O., KARTAL, S., (2015), "Atatürk Caddesi Kent İmajı Öğelerinin Zamansal Değişimi”, Uluslararası Hakemli Mimarlık ve Tasarım Dergisi (MTD), Sayl: 05 İlkbahar Yaz, S:39-58, Doi: 10.17365 / TMD.2015511327

BOZDOĞAN, Sibel, (2008), Art and Architecture in Modern Turkey: The Republican Period, Kasaba, R. (Ed.). London: Cambridge University, p.419-471

CARMONA, Matthew, (2010), Contemporary public space, part two: classification. Journal of urban design, 15(2), 157-173.

ERTIN, Gaye, (1994), Eskişehir Kentinde Yerleşmenin Evrimi, Eskişehir: Anadolu Üniversitesi

GOLDBERGER, Paul, (1996), The Rise of the Private City, Carmona, M., Tiesdell, S. (Ed.). Oxford: Elsevier. p.170-176

HARVEY, David, (2006), The political economy of public space, The politics of public space, p.17-34.

KOSTOF, Spiro, (1985), The Study of What We Built in A History of Architecture: Settings and Rituals, New York: Oxford

LEFEBVRE, Henry, (1973), The Production of Space, Leach, N. (Ed.). London and New York: Routledge. p. 139-148

LYNCH, Kevin, (1990), "The Openness of the Open Space (1965)", in City Sence and City Design, Cambridge, Massachusetts, London, England: MIT

OLDENBURG, Ray, (2007), The Character of Third Places, Carmona, M., Tiesdell, S. (Ed.). Oxford: Elsevier. pp.170-176

ÖZDEMIR, E. ve CENGiZOĞLU, P. (2016), "Çağdaş Alışveriş Merkezlerinde Kamusal Mekân Nitelikleri Ve Mersin Forum Avm Örneği” Uluslararası Hakemli Mimarlık ve 
Tasarım Dergisi (MTD), Sayı: 07 Kış İlkbahar, S:55-72, Doi: 10.17365 / TMD.2016716507

SENNETT, Richard, (1999), Gözün Vicdanı: Kentin Tasarımı ve Toplumsal Yaşam, İstanbul: Ayrıntı

ÜSTÜN, B. ve TUTAL, O. (2008), "Tüketim Alışkanlıklarındaki Değişimler ve Bu Değişimlerin Alışveriş Mekânlarına Etkisinin Eskişehir Örneğinde İrdelenmesi”, Anadolu Üniversitesi Sosyal Bilimler Dergisi, Cilt:08, Sayı:2

\section{ONLINE SOURCES}

www.eskisehir.net (last visited on 30th December 2015)

www.googleearth.com (last visited on 30th December 2015)

www.googleearth.com (last visited on 21st October 2020) 